\title{
İç Göçün Nedenleri ve Değerlendirilmesi: Bitlis İli Örneği ${ }^{1}$
}

DOI: 10.26466/opus.562603

*

\section{$\underline{\text { Vedat Ylmaz }}$}

* Dr.Öğretim Üyesi, Van Yüzüncü Yıl Üniversitesi,IİBF Kamu Yönetimi Bölümü, Van / Türkiye E-Posta: vedatyilmaz1977@gmail.com

ORCID: 0000-0003-4624-9824

\section{Öz}

Dünyayı meşgul eden en önemli konulardan biri de göç konusudur. Göç bütün ülkelerin ortak sorunu olmasından dolayı evrensel bir sorundur. İnsanların coğrafik ifade ile yer değiştirmesi durumu olarak tanımlanan göç konusu yüzyıllardan beri süre gelen bir olgudur. İnsanlar; sosyal, kültürel, ekonomik, yönetimsel, çevresel gibi faktörlerden kaynaklı olarak göç etmek zorunda kalmıştır. Yapılan göçlerin az da olsa bir kısmı gönüllü olmakla birlikte genelde büyük çoğunluğu zorunlu haller sonrası gerçekleşmektedir. Türkiye'de 1950'li yıllardan sonra iç göç artış göstermiştir. Özellikle Doğu ve Güneydoğu Anadolu bölgesinde yaşayan insanlarm ülkenin batısına doğru göç ettiği izlenmiştir. Çalışmada; yerel halkın doğup büyüdüğ̈̈ toprakları terk etmesine neden olan etkenlerin ortaya çıkarılması ve değerlendirilmesi amaçlanmıştır. Bu bağlamda, Doğu Anadolu Bölgesinde yer alan Bitlis ili örneklem olarak alınmıştır. Araştırmada veri toplama yöntemi olarak anket yöntemi kullanılarak, Bitlis il mülki sınırları içerisinde belirli bir süre yaşayıp sonradan göç etmiş olan 280 katılımoı ile anket yapılmıştır. Anket çalışması sonrası elde edilen verilerin analiz edilmesi amacıyla SPSS 22 paket programı kullanılmıştır.

Anahtar Kelimeler: Göç, Yerel Halk, Kent, Bitlis

\footnotetext{
${ }^{1}$ Bu çalışma 27-28 Nisan 2018 tarihinde HEGEM Şiddetle Mücadele Vakfı tarafından Samsun ilinde düzenlenen Şiddet ve Sosyal Travmalar Uluslararası Sempozyumunda sunulan "iç̧ Göçün Sebepleri ve Değerlendirilmesi: Bitlis Örneği" başıılı çalışmanın güncellenmiş halidir.
} 


\title{
Causes of Internal Migration and Evaluation: Province of Bitlis Example
}

\begin{abstract}
One of the most important issues that occupy the world is migration. Immigration is a universal problem because it is a common issue for all countries. Immigration, which is expressed as the state of geographical displacement of people, has been a phenomenon that has been going on since centuries. People have faced to migrate because of social, cultural, economic, administrative and environmental factors. Although a small part of the migrations are voluntary, the majority of them usually occur after mandatory cases. Internal migration has increased in Turkey after the year 1950. Especially people living in Eastern and Southeastern Anatolia regions have been observed to migrate towards the west of the country. In this study, it is aimed to reveal and evaluate the elements that cause the local people to leave the lands where they were born and raised. In this context, the province of Bitlis in the Eastern Anatolia Region was taken as a sample. In the study, a questionnaire was conducted with 280 participants who lived in Bitlis province in a certain period of time then migrated. SPSS package program was used for the analysis of the data obtained after the questionnaire study.
\end{abstract}

Keywords: Migration, local people, urban, Bitlis 


\section{Giriş}

İnsanlık tarihi ile birlikte ortaya çıkan göç kavramı; insanların geçim sorunu, temel ihtiyaçlarını karşılayamama, deprem, sel gibi doğal afetler, toplumların birbirleri arasında çıkan çatışmalar benzerindeki neden ve nedenlerden dolayı bulunduğu yerden başka bir yere taşınması sürecidir. Zamanla göçün nedenleri çeşitlilik göstererek, belirli kentlerin sosyal, kültürel, eğitimsel, ekonomik gibi alanlarda daha çok gelişmesi ile birlikte az gelişmiş ya da gelişmemiş olan yerleşim alanlarından gelişmiş yerleşim alanlarına doğru insanlar göç etmeye başlamıştır. Böylelikle insanların göç ettiği kentler daha da büyüyüp gelişmiş, diğer yerlerde ise aksine daha da küçülmüş ve gelişiminin önü de kesilmiştir.

Nüfus olgusu kentlerin gelişiminde önemli bir güçtür. Önemli olan bu güçten doğru ve zamanlı olarak faydalanılmasını bilmektir. Kentlerde nüfusun artmasının başlaması ile birlikte gelecekte daha da çok artacağı hesaba katılarak gerekli olan alt yapı hazırlıkları yapılırsa kente ki artan nüfus kentin birçok alanda gelişiminde önemli rol üstlenir. Aksi durumda ise kentte yeni sorunların ortaya çıkması kaçınılmaz olur.

Dünyadaki tüm ülkelerde olduğu gibi Türkiye'de de hem göç eden hem de göçle gelen insanlar olduğu gibi ülkenin kendi sınırları içinden de, bir yaşam alanından başka bir yaşam alanına göç yapılmaktadır. Ülke sınırları içerisinde yapılan göçe iç göç, ülke sınırları dışına yapılan göçe ise dış göç adı verilmektedir. Bu şekilde insanlar zaman zaman yerleşim alanlarını belirli nedenlerle zorunlu olarak değiştirmektedir.

Türkiye'de 1950'li yıllardan sonra göç dalgası hız kazanmıştır. Özellikle Doğu ve Güneydoğu Anadolu Bölgesinden batıda yer alan bölgelere göç akışı artmıştır. Çalışmada; son yıllarda adından nadir olarak bahsedilen iç göç hakkında bilgilendirmeler yapılmaya çalışılmıştır. Bu bağlamda, insanların doğup büyüdüğü yerleşim alanlarından başka yerleşim alanlarına göç etmelerine neden olan unsurları ortaya çıkarmak amacıyla Doğu Anadolu Bölgesinde yer alan ve köklü bir tarihi geçmişe sahip olan Bitlis ili örneklem olarak alınmıştır. Bitlis ili sınırları içerisinde belirli bir zaman dilimi yaşayıp göç eden 280 katılımcıya 20 Ocak 2017 ile 15 Mart 2017 tarihleri arasında anket çalışması yapılmış olup, anketlerden elde edilen veriler, SPSS (Statistical Package for Social Science 22.0) istatistik paket programı kullanılarak, analizler yapılmış ve yorumlamalarda bulunulmuştur. 
Ayrıca çalışmada, göç kavramı ve Türkiye'de iç göçün nedenlerine yönelik bilgilendirmeler yapılarak çözüm önerilerinde bulunulmuştur.

\section{Göçe İlişkin Kavramlara Bakış}

Göç olgusu durağan olmayan dinamik bir yapıda, toplumların yapısına göre farklılık gösterebilen ve farklı içeriğe sahip olması ile birlikte çeşitli bağlamlarda ele alınan bir kavram olması, göçün tanımının yapılmasını zorlaştırmaktadır (Akşit, 1998, s.67; Gündüz ve Yetim, 1997, s.110; İçduygu ve Ünalan, 1998, s.38; Sarıteke vd, 2018, s.388). Literatüre bakıldığında, göçe ilişkin farklı tanımlar yapılmış olsa da genelde hemen hemen tamamında ele alınan ortak düşünce, zaman ve mekan boyutu olduğu söylenebilir. Fakat göçün sebepleri ve sonuçları itibariyle toplumsal yapıdaki köklü değişimlere sebep olan en önemli toplumsal bir olay olması onu belirli bir süreç dahilinde salt demografik bir nüfus eylemi (Faist, 2003, s.41; Özer, 2004, s.11; Eren ve Aydın, 2016, s.33-34) ya da coğrafik bir mekan değişikliği (Gündüz ve Yetim, 1997, s.110; İçduygu ve Ünalan, 1998,s.38; Karpat, 2010, s.71; Keleş, 1998, s.58; Tekeli, 2008,s.18) olarak görmek tam bir tanım olmayacaktır. Çeşitli tanımlamaların yapıldığı göç kavramının kapsamlı bir tanımı için gerekli olan üç modellemeden söz edilebilir. Birinci model, göç akışlarının yer bağlamından yola çıkarak uluslararası ve iç göç ayrımının yapılmasıdır. Uluslararası göç çalışmaları, insanların farklı ülkelerdeki hareketlerini, iç göç ise ulusal sınırlar içerisinde insanların yer değiştirmesini ela alır. İkinci önemli konu göç modellemesidir, bu modeldeki önemli bir ayrım mikro ve makro yaklaşımlar arasındadır. Mikro yaklaşım, kişilerin davranışlarına odaklanırken, makro yaklaşım siyasi ve mekansal sınırlara (ülkeler, bölgeler, belediyeler) odaklanmaktadır. Üçüncü ve son model ise göçün belirleyicilerini tanımlamak veya göçün sonuçlarını keşfetmek için yönlendirilebilecek olan çalışmanın maksadına atıfta bulunulmasıdır (Etzo, 2008, s.2).

Belirtilen modeller dikkate alınarak göçün iyi bir şekilde anlaşılması için sosyal ve ekonomik yapının iyi bilinmesi gereklidir. Çünkü göç olgusu sosyal ve ekonomik yapıdan bağımsız bir şekilde hareket etmez ve ekonomideki yapısal değişimleri en iyi şekilde yansıtan göstergeler 
arasında yer alır (Üner, 1974, s.9) Göç süreci, zaman, neden ve sonuç etkenleri bakımından, durağan bir olgudan çok dinamik bir süreç olduğundan tanımlanması, çözüm bulunması, ölçülmesi, açıklanması ve yorumlanması konuları hem kuramsal hem de görgül anlamda karmaşık hale gelmektedir. Göç olgusunun bu karmaşıklığı içerisinde bir yandan uzun bir sürecin farklı ancak birbirleri ile ilişkili birimlerinin toplamı olarak ela alınarak, diğer yandan da farklı bilimsel disiplinlerin çok özgül konuları olarak değişik boyutları ile incelendiğini söyleyebiliriz (İçduygu ve Ünalan, 1998, s.38).

Göç olayı; toplumların sosyal, ekonomik ve kültürel yapılarında değişiklik yapan en önemli faktörlerden birisidir. Başka bir ifadeyle, göç olayı toplumsal yapıyı etkilemekle beraber onu değiştirici özelliğe sahiptir. Türkiye'de yarım yüzyıldan fazladır, önemli yapısal sorunların başında gelen olgudur. Demografik yapıda meydana gelen bu mekânsal dağılım, hem göç veren hem de göç alan yerleşim alanlarında kendini göstermiştir. Yaşanan bu sürecin farklı nedenleri olmasıyla birlikte, belli bir yerde başlayan ve biten bir sürecin çok daha ötesinde olmuştur. Günümüzde de bu sürece neden olan ve besleyen birçok unsur, toplumsal hareketliliğin öncelikli nedenini oluşturmaktadır. Türkiye'de özellikle sosyal, ekonomik ve kültürel nedenlerle göçler olduğu gibi güvenlik korkusu nedenleriyle de göçler yapılmaktadır. Önceleri kırdan kente göçler daha yaygınken, günümüzde çoğunlukla kentten kente göçlerin gerçekleştiği dikkat çekmektedir (Bulut ve Eraldemir, 2015, s.14-15). Türkiye tarihinin her döneminde görülen göç olgusu farklı çeşitleri ile gündemi meşgul etmiştir (Kocak ve Terzi, 2012).

Türkiye'de insanların göç etmelerindeki en önemli faktörün ekonomik faktör olduğu rahatlıkla söylenebilir. Özellikle ekonomik anlamda daha zayıf yerleşim alanlarında yaşayan insanların ekonomik anlamda daha iyi durumda olan ya da daha iyi durumda olduğunu düşündükleri büyük yerleşim alanlarında iş bulmak ve yaşamlarını daha iyi hale getirmek düşüncesi ile göç hareketlerini gerçekleştirmektedirler. Yapılan göç sonrasında kimi insanlar amacına ulaşabilmekte kimileri ise amaçlarına ulaşamayıp başka yerlere ya da göç ettiği yerleşim alanına geri dönebilmektedir. 


\section{Türkiye'de İç Göçün Tarihi ve Sebepleri}

Türkiye'de, Türkiye Cumhuriyeti'nin kurulduğu ilk dönemlerde tam anlamıyla bir köylü toplumu görünümü vardı. 1927 yılında yapılan ilk nüfus sayımına göre, toplam nüfus arasında köylü nüfusun oranı $\% 75,8$ 'dir. Diğer bir ifade ile kentlerin (şehirlerin) oranı $\% 24,2$ 'dir. Belirtilen oranlar 1950'li yıllara kadar çok az değişim göstererek devam etmiştir. Bu tarihler sonrasında ise nüfus artış hızında ve kent-köy yerleşim dengelerinde önemli düzeyde değişimler oluşmaya başlamıştır (Keleş, 1997, s.167). Yıllara göre bu değişim sürecini rahatlıkla gözlemleyebiliriz. 1950 yılında Türkiye'de bulunan il sayısı 63, kentlerdeki nüfus oranı \%18,1'dir. 1960 yılında il sayısı 67'e, kentlerdeki nüfus oranı ise \%26,3'e yükselmiştir. 1970 yılında kentte yaşayan nüfusun oranı \%35,8'e, 1980 yılında ise $\% 45,4^{\prime} \mathrm{e}$ çıkmıştır. 1990 yılına gelindiğinde, il sayısı 73 ve kente yaşayan nüfusun toplam nüfusa oranı da \%56,3'e yükselmiştir. 2000 yılında yapılan genel nüfus sayımı dönemindeyse il sayısı 81 'e, kentteki nüfusun oranıysa \%65'e yükselmiştir (Başel, 2007, s.517).

Genel anlamda 1950'li yıllardan sonra yaşanan kapitalistleşme süreci ile birlikte sanayileşme ve artan makineleşme kırsal alandaki toprak ile nüfus arasındaki dengeyi bozması, toprak mülkiyetinde kutuplaşma benzerindeki nedenler üretim dışında kalan iş gücünün yeni geçim kaynağ1 sağlamak için büyük kentlere göç etmeye başlamıştır. Toplumsal, sosyoekonomik ve siyasal nedenlerin sebep olduğu iç göç, gelişmemiş yerleşim alanlarından gelişmiş yerleşim alanlarına doğru gerçekleşmektedir. 1980'li yıllara gelindiğinde göçe sebep olan unsurlar arasına terör olayları da girmiştir. Özellikle son ylllarda Türkiye'nin Doğu Anadolu ve Güneydoğu Anadolu bölgesinden ülkenin daha batısında yer alan bölgelere yapılan göç artış göstermiş̧tir. Yapılan bu göç neticesinde de göç edilen bölgelerdeki kent merkezlerinde, sosyo-kültürel ve ekonomik bakımdan önemli değişiklikler meydana gelmiştir (İnan, 2004, s.24).

Göçlerin temel nedeni olarak ülkedeki sosyal ve ekonomik olanakların çeşitli şekillerde farklılık göstermesi, başka bir ifade ile iller ve bölgelerarasında gelişme farklılığının olmasıdır. Bölgeler arası görülen bu dengesizlik hem iç göçlerin nedeni hem de sonucu olarak kısır bir döngüye yol açmıştır. Üretilen toplumsal refahın dengesiz bir şekilde dağıtılması göçe sebep olmakla birlikte dengesizliği de belirginleştirmektedir 
(Başel, 2007, s.520). Türkiye'de görülen bu dengesizlik; doğudan batıya doğru iç göçün artmasına ve doğudaki kentler ile batıdaki kentler arasındaki gelişmişlik düzeyinin de oldukça birbirinden uzaklaşmasına neden olmuştur. Başka bir ifadeyle nüfusun ve sermayenin bölgelere göre dengesiz dağılımı, refahın paylaşımı bakımından da bölgeler arasında eşitsizlikleri oluşturmaktadır (Keleş, 1997, s.185). Bu durum da bölgelerarası göçü hızlandırmıştır. Türkiye'deki bölgelerarası iç göç hareketliliği özellikle; Doğu Anadolu Bölgesi, Güneydoğu Anadolu Bölgesi ve Doğu Karadeniz Bölgesi'nden ülkenin batısında bulunan bölgelere doğru gerçekleşmektedir (Akan ve Arslan, 2008, s.20). Çünkü belirtilen bölgelerdeki yaşam koşulları batıdaki bölgelere göre daha gelişmemiştir. Özellikle batıda ekonomik, sosyal, kültürel gibi bir çok alanda gelişmiş ve insanların olanaklarının üst seviyede olduğu Marmara Bölgesine daha fazla göç edilmektedir.

\section{Alan Araştırması Yapılan Bitlis İlinin Sosyo-Ekonomik Özellikleri}

Bitlis ili Doğu Anadolu Bölgesinde yer alan bir ilimiz olup; güneyinde Siirt ili, batısında Muş, kuzeyinde Ağrı ve doğusunda Van ili yer almaktadır. Bitlis ili tarihi açıdan kaleleri ve Türk İslam eserleri ile önemli olan bir ilimizdir. Özellikle Selçuklu ve Osmanlı dönemlerine ait eserler bulunmaktadır. Bitlis ilinin tarihine bakıldığında; Tarihçiler M.Ö. 5000 ile 7000 yıllarına kadar dayandırmaktadır. Gerçek anlamda Bitlis ilinin tarihi Neolotik Çağ (Yenitaş ya da Cilalı Taş Devri) dönemine kadar uzanmaktadır. Hititler, Asurlular, Urartular, İskitler, Medler, Persler, Romalılar, Bizanslılar, Selçuklular, Beylikler ve Osmanlı uygarlıklarına ilişkin kalıntılar bulunmaktadır. Tarih boyunca kültür ve sanat eserlerinin yoğun olarak görüldüğü Bitlis ili, kültürel ve doğal güzellikler bakımından epey zengin bir kenttir. Nemrut Dağı ve Krater Gölleri ile Van Gölünün yarısı Bitlis ili sınırları içerisinde yer almaktadır (Serdar, 2010, s.4 ; www.bitliskulturturizm.gov.tr, 2019). Günümüzde Türkiye'nin Doğu Toroslarını oluşturan ve Hakkari ilindeki Cilo Dağlarına kadar uzanan bu dağlar, geniş bir kavisle yükselmekte, geniş ve sıradağlar oluşturduğu için aşılmasını çok zorlaştırmıştır. Bitlis ili; bir set görevi oluşturan bu dağların kısmen daraltılmış olduğu bir vadinin bulunduğu yerde kurulmuştur. Bu sebepten dolayı seyyah ve araştırmacılar Bitlis ili için "Vadideki Yeşil Şehir" adını 
kullanmışlardır. Bu özellikleri ile Bitlis ili, Van Gölü havzasını Güney Doğu Anadolu bölgesine bağlamaktadır. Özellikle Anadolu'nun batısından gelerek Harput, Bingöl, Solhan, Muş ve Bitlis ili üzerinden İran'a giden yol güzergahı ile Musul, İskenderun, Adana, Gaziantep, Urfa, Diyarbakır ve Bitlis ili üzerinden kuzeye giden yol güzergahı ilin stratejik anlamdaki önemini artırmıştır. Bitlis ili; merkez ilçe hariç olmak üzere Adilcevaz, Ahlat, Güroymak, Hizan, Mutki ve Tatvan olmak üzere altı ilçe ile birlikte 14 bucak, 334 köy ve 295 mezraya sahip olan bir kenttir (Serdar, 2007, s.13).

Bitlis ilinin 2018 yılı itibariyle nüfusu 349.396'dır. Nüfus açısından en kalabalık iller arasında 55. sırada bulunmaktadır. Yüzölçümü $8.855 \mathrm{~km}^{2}$ ve nüfus yoğunluğu açısından $\mathrm{km}^{2 \prime}$ ye 39 kişi düşmektedir (www.nufusu.com, 2019). İlin ekonomisine bakıldığında; tarım, hayvancılık ve ormancılığa dayandığı görülmektedir. Nüfusun \%80'i tarımla uğraşmakta olup, hayvancılıkla daha çok göçebe aşiretlerin uğraştı̆̆ı, genelde koyun, keçi ve sığır beslenildiği, arıcılığın geliştiği, ormancılık ise en çok Hizan, Mutki ve Tatvan ilçelerinde görülmektedir (www.cografya.gen.tr, 2019). Ayrıca Adilcevaz ilçesi cevizi ile tanınmaktadır. Cevizlerin özelliği ince kabuklu, içi beyaz, kabuktan ayrılması kolay ve büyük olmasıdır. 1989 yılından beri Adilcevaz'da ceviz festivali düzenlenmektedir.

Bitlis ili altı ilçeye sahip olup, merkez ve ilçelere ait nüfus ile ilçelerin merkeze uzaklığına ilişkin bilgiler aşağıdaki tabloda yer almaktadır.

Tablo 1. Bitlis İl ve İlçelerine İlişkin 2018 Yılı İstatistiki Bilgiler (www.nufusu.com, 2019; http://www.illerarasimesafe.com/, 2019).

\begin{tabular}{lllll}
\hline İlçe Adı & Nüfusu & Toplam Nüfus \%'si & $\begin{array}{l}\text { Merkezden } \\
\text { KM }\end{array}$ & Uzaklığ́ \\
\hline Merkez & 71.501 & 20,46 & - & \\
Adilcevaz & 30.376 & 9,18 & 86 & \\
Ahlat & 40.806 & 11,68 & 62 & \\
Güroymak & 47.742 & 13,66 & 52 & \\
Hizan & 34.186 & 9,78 & 21 & \\
Mutki & 32.090 & 9,18 & 24 & \\
Tatvan & 92.695 & 26,53 & & \\
\hline
\end{tabular}

Bitlis il ve ilçelerine ilişkin istatistiki bilgilerin yer aldığ1 tablo 1 incelendiğinde; Bitlis ilinin 2018 yılında en fazla nüfusa sahip olan ilçesinin Tatvan İlçesi (92,695 kişi) olduğu ve en az nüfusa sahip olan ilçesinin 
ise Adilcevaz (30.376) olduğu, Bitlis şehir merkezi ile ilçeler arasındaki karayolu ile ulaşım mesafesine bakıldığında; Bitlis şehir merkezi ile Adilcevaz ilçesi arası $86 \mathrm{~km}$, Ahlat ilçesi arası 62 km, Güroymak ilçesi $32 \mathrm{~km}$, Hizan ilçesi $52 \mathrm{~km}$, Mutki ilçesi $21 \mathrm{~km}$ ve Tatvan ilçesi ise $24 \mathrm{~km}$ olduğu görülmektedir. Bu verilere göre, Bitlis il merkezinden en uzak ilçesinin Adilcevaz olduğunu ayn zamanda il merkezinin en uzak mesafede olan Adilcevaz ilçesinin diğer ilçelere göre nüfusunun da en az olması dikkat çekmektedir. Genel olarak tablo yorumlandığında; Tatvan ilçesinin, ilin merkez nüfusundan daha fazla bir nüfusa sahip olduğu, gelişmişlik bakımından da Tatvan ilçesinin il merkezinden daha gelişmiş olduğunu söyleyebiliriz. Tatvan ilçesinin gelişmesindeki en önemli etkenin Van Gölüne kıyısı olması ve Van ili ulaşım güzergahının kısa mesafede olduğ $\mathrm{u}^{2}$ bir yerleşim alanında kurulmuş olduğunu söyleyebiliriz. Ancak aynı Van Gölüne kıyısı bulunan Adilcevaz ve Ahlat ilçeleri için bu durumdan bahsetmek güçtür. Çünkü Van iline gidilmesi için gölün diğer çevresinden dolaşılması gerekir bu da hem zaman kaybı hem de mesafenin uzun olmasından dolayı tercih edilen bir güzergah olmamasından kaynaklı olduğunu söyleyebiliriz.

\section{Bitlis İli ve Göç}

Bitlis ili belirtildiği gibi ülkemizin Doğu Anadolu Bölgesinde yer alan ve sürekli olarak göç veren bir istatistiki yapıya sahip olan bir ilimizdir. Bitlis ilinde göçlerin geneli batı bölgelerine olmakla birlikte bölge içi göçlerde görülmektedir. Bitlis ilinden çoğunlukla göç edilen iller aşağıdaki tabloda belirtilmiştir.

2017 ve 2018 yıllarında Bitlis ilinden 200 kişi ve üzeri göç edilen illeri gösterir tablo 2 incelendiğinde; başta İstanbul olmak üzere, Ankara, Adana, Antalya, Aydın, Bursa, İzmir, Kocaeli, Manisa, Mersin ve Tekirdağ illerine göç edilmesinin yanında doğu ve güneydoğu Anadolu bölgesinde yer alan, Gaziantep, Malatya, Muş, Batman, Siirt ve Van illerine Bitlis ilinden göç edildiği görülmektedir. Bitlis ili genel anlamda her dönem göç veren bir il konumunda olmuştur.

\footnotetext{
2 Van iline Bitlis ilinden Van gölünün iki tarafındanda ulaşım sağlanmaktadır. Birisi Ahlat-Adilcevaz-Erciş güzergahı, mesafesi uzun olan diğeri ise Tatvan- Gevaş-Edremit-Van güzergahıdır.
} 
Tablo 2. 2017 - 2018 Yıllarında Bitlis İlinden Göç Edilen İllerin Dă̆ılımı (TUİK, 2019).

\begin{tabular}{lll}
\hline Bitlis İlinden Göç Edilen İl & 2017 Yılı Sayı & 2018 Y11 Sayı \\
\hline ADANA & 433 & 381 \\
ANKARA & 1.420 & 1.138 \\
ANTALYA & 457 & 335 \\
AYDIN & 335 & 368 \\
BATMAN & 443 & 392 \\
BURSA & 903 & 786 \\
GAZİANTEP & 261 & 213 \\
İSTANBUL & 4.569 & 4.060 \\
IZMİR & 857 & 728 \\
KOCAELI & 410 & 461 \\
MALATYA & 208 & 235 \\
MANISA & 522 & 455 \\
MERSiN & 925 & 775 \\
MUŞ & 549 & 644 \\
Sİ̈T & 404 & 385 \\
TEKİRDAĞ & 203 & 200 \\
VAN & 845 & 734 \\
\hline
\end{tabular}

Tablodaki bilgiler ışığında; Bitlis ilinde en fazla göçün 2017 (4.569 kişi) ve 2018 yılında (4.060 kişi) İstanbul iline yapıldığı görülmektedir. Ardından Ankara (1420 kişi), Mersin (925 kişi), Bursa (903 kişi) ve İzmir (857 kişi) illeri sırası ile gelmektedir.

\section{Araştırmanın Yöntemi ve Sınırlılıkları}

Araştırmanın temel amacl; yerel halkın doğup büyüdüğü toprakları terk etmesine neden olan etkenlerin ortaya çıkarılması ve değerlendirilmesidir. Bu bağlamda, Doğu Anadolu Bölgesinde yeralan Bitlis ili örneklem olarak alınmıştır. Çalışmada; literatür taraması, yazınsal ve görsel kaynakların kullanılmasının yanında veri toplama yöntemi olarak anket tekniğinden faydalanılmıştır. İlgili anket, Bitlis il mülki sınırları içerisinde belirli bir süre yaşayıp sonradan göç etmiş olan 280 katılımcıyla yapılmıştır. Anket çalışması sonrası elde edilen verilerin analiz edilmesi için SPSS 22 paket programı kullanılmıştır.

\section{Araştırmanın Varsayımları ve Sınırlılıkları}

Araştırmaya yönelik varsayımlar şunlardır: 
- Veri toplama aracı olarak kullanılan anket sorularının her birindeki değerler arasındaki farklılığın katılımcılar tarafından ayırt edilebileceği varsayılmıştır.

- Araştırmada veri toplama aracı olarak kullanılan anketin konuya yönelik bütün detayları kapsadığı varsayılmıştır.

- Anket çalışmasında katılımcıların ankette yer alan sorulara verdiği cevapların gerçek durumu yansıttığı varsayılmıştır.

- Araştırmada katılımcilara uygulanan anketlerin katılımcilar tarafından samimi ve doğru olarak yanıtlandığı, ayrıca verilen cevapların geçerli ve güvenilir olduğu, verilerin analizinde kullanılan istatiksel yöntemlerin amacına uygun olduğu varsayılmaktadır.

Araştırmanın bir alan araştırması olması nedeniyle ulaşım, zaman ve maliyet unsuru gözönüne alınarak Doğu Anadolu Bölgesinde bulunan; 14 il (Malatya, Erzincan, Elazı $\breve{g}$, Tunceli, Bingöl, Erzurum, Muş, Bitlis, Kars Ağrı, Ardahan, Iğdır, Hakkari, Van) arasından Bitlis ili ile sınırlandırılmıştır.

\section{Araştırmanın Bulguları}

Çalışmanın bu kısmında elde edilen bulguların analiz edilmesi sonrası elde edilen sonuçlar yorumlanarak konuyla ilgili öneriler verilmiştir.

Tablo 3 incelendiğinde; araştırmaya katılanların 151'i $(\% 53,9)$ erkek katılımcı, 129'u (\%46,1) ise kadın katılımcıdan oluşmuştur. Erkek katılımcı sayısı kadın katılımcı sayısından $22(\% 7,8)$ katılımcı fazla olduğu görülmektedir.

Katılımcıların doğum yerlerine bakıldığında; 107 katılımcı $(\% 38,2)$ il merkezinde doğmuş iken, 95 katılımcı $(\% 33,9)$ ilçe merkezinde, 17 katılımcı $(\% 6,1)$ kasabada (belde belediyesi), 60 katılımcı (\%21,4) köyde ve 1 katılımcı $(\% 0,4)$ ise yurt dışında doğduğu görülmektedir.

Katılımcıların yaş grup dağılımlarını incelediğimizde; araştırmaya katılanların 53'ü (\%18,9) 18 ile 25 yaş arasında yer alırken, 93'ü $(\% 33,2) 26$ ile 30 yaş arasında, 34'ü $(\% 12,1) 31$ ile 35 yaş arasında, 26 's1 $(\% 9,3) 36$ ile 40 yaş arasında, 34'ü $(\% 12,1) 41$ ile 45 yaş arasında ve 40'1 $(\% 14,3) 46$ ve üzeri yaş arasındadır. Katılımcıların çoğunluğu olan 93'ü $(\% 33,2) 26$ ile 30 yaş arasında olduğu görülmektedir. 
Tablo 3. Katılımcıların Demografik Özelliklerine İlişkin Tanımlayıcı Bilgiler

\begin{tabular}{|c|c|c|c|}
\hline \multicolumn{2}{|l|}{ Değişkenler } & \multirow{2}{*}{$\begin{array}{l}\mathbf{F} \\
151\end{array}$} & \multirow{2}{*}{\begin{tabular}{|l|} 
\% \\
53,9
\end{tabular}} \\
\hline & Erkek & & \\
\hline Cinsiyet & Kadın & 129 & 46,1 \\
\hline \multirow{5}{*}{ Doğum Yeri } & İl merkezi & 107 & 38,2 \\
\hline & İlçe & 95 & 33,9 \\
\hline & Kasaba & 17 & 6,1 \\
\hline & Köy & 60 & 21,4 \\
\hline & Yurt diş1 & 1 & 0,4 \\
\hline \multirow{6}{*}{ Yaş } & $18-25$ & 53 & 18,9 \\
\hline & $26-30$ & 93 & 33,2 \\
\hline & $31-35$ & 34 & 12,1 \\
\hline & $36-40$ & 26 & 9,3 \\
\hline & $41-45$ & 34 & 12,1 \\
\hline & 46 ve yukarısı & 40 & 14,3 \\
\hline \multirow{2}{*}{ Medeni Durum } & Evli & 178 & 63,6 \\
\hline & Bekar & 102 & 36,4 \\
\hline \multirow{5}{*}{ Meslek } & Memur & 74 & 26,4 \\
\hline & İşçi & 104 & 37,1 \\
\hline & Esnaf & 40 & 14,3 \\
\hline & Çiftçi & 17 & 6,1 \\
\hline & Diğer & 45 & 16,1 \\
\hline \multirow{8}{*}{ Öğrenim Durumu } & Okuryazar değil & 36 & 12,9 \\
\hline & Okuryazar & 73 & 26,1 \\
\hline & İlköğretim & 72 & 25,7 \\
\hline & Lise & 33 & 11,8 \\
\hline & Yüksekokul 2 yıllık & 23 & 8,2 \\
\hline & Yüksekokul 4 yıllık & 38 & 13,6 \\
\hline & Yüksek lisans & 5 & 1,8 \\
\hline & Doktora & - & - \\
\hline
\end{tabular}

Katılımcıların medeni durumlarına baktığımızda; 178 katılımcı $(\% 63,6)$ evli iken 102 katılımcı $(\% 36,4)$ bekardır. Katılımcıların çoğunluğunun evli olduğu görülmektedir. Katılımcıların meslek grupları incelendiğinde; katılımciların 74' ̈̈ $(\% 26,4)$ memur iken, 104'ü $(\% 37,1)$ işçi, 40'1 $(\% 14,3)$ esnaf, 17'si (\%6,1) çiftçi ve 45'i (\%16,1) diğer meslek gruplarını oluşturmaktadır. Meslek gruplarında en fazla işçi olan katılımcı sayısının (104) olduğu görülmektedir. Katılımcıların öğrenim durumlarına baktığımızda; $36(\% 12,9)$ katılımcı okuryazar değil iken, 73'ü $(\% 26,1)$ okuryazar, 72'ü (\%25,7) ilköğretim, 33'ü (\%11,8) lise, 23'ü (\%8,2) yüksekokul 2 yıllık (Ön lisans), 38'i (\%13,6) yüksekokul 4 yıllık (Lisans) ve 5'i (\%4,7) yüksek lisans mezunudur. Katılımcıların çoğunluğu (181 katılımcı) İlköğretim ve aşağısında öğrenim durumuna sahip olduğu görülmektedir. 
Tablo 4. Katılımcıların Bitlis İlinden Ne Kadar Zamandan Beri Göç Ettiklerine İlişkin İstatistiki Bilgiler

\begin{tabular}{|c|c|c|c|}
\hline Değişkenler & & $\mathbf{F}$ & $\%$ \\
\hline \multirow{7}{*}{ Süre } & $1 Y_{1}$ ve $A s ̧ a ̆_{1}$ & 53 & 18,9 \\
\hline & 1-5 Yil & 40 & 14,3 \\
\hline & 6-10 Yil & 55 & 19,6 \\
\hline & 11-15 Y1l & 35 & 12.5 \\
\hline & 16-20 Yil & 84 & 30,0 \\
\hline & 20 Yil ve Yukarısı & 13 & 4,6 \\
\hline & Toplam & 280 & 100 \\
\hline
\end{tabular}

Tablo 4'de katılımcıların Bitlis ilinden ne kadar zamandan beri göç ettiklerine ilişkin süreleri incelendiğinde; 1 yıl ve aşağısında göç eden katılımcı sayısı 53 (\%18,9) iken, 40'1 (\%14,3) 1 ile 5 yıl arasında, 55'i $(\% 19,6)$ 6 ile 10 yıl arasında, 35'i (\%12,5) 11 ile 15 yıl arasında, 84'ü (\%30,0) 16 ile 20 yıl arasında ve 13'ü $(\% 4,6) 21$ yıl ve üzerinde bir süredir illerinden göç ettiği bilgileri yer almaktadır. Katılımcların Bitlis ilinden ne kadar zamandan beri göç ettiklerine ilişkin sürelere baktığımızda, 16-20 yıl arasında göç etmiş olan (84 Katılımcı) katılımcı sayısının çoğunlukta olduğu görülmektedir. Ayrıca tabloda toplam katılımcların hemen hemen yarısı 10 yıl sürenin hem üzerinde hem de aşağısındaki sürelerde göç etmiş oldukları göze çarpan veriler arasındadır.

Tablo 5. Katılımcıların Göç Ettiği İkamet Yerlerine İlişkin İstatistiki Bilgiler

\begin{tabular}{llll}
\hline Değişkenler & & F & \% \\
\hline \multirow{3}{*}{ İkamet Ettiğiniz Yer } & Büyükşehir Belediyesi Olan İl & 211 & 75,4 \\
& İl Belediyesi Olan İl & 54 & 19,3 \\
& İlçe Belediyesi Olan & 15 & 5,4 \\
& Toplam & 280 & 100,0 \\
\hline
\end{tabular}

Tablo 5 incelendiğinde; katılımcıların 211'i $(\% 75,4)$ büyükşehir belediyesi olan bir ile göç etmiş iken, $54(\% 19,3)$ katılımcı il belediyesi olan ve 15 $(\% 5,4)$ katılımcının ise ilçe belediyesi olan yerleşim alanına göç ettiği bilgileri yer almaktadır. Katılımcıların göç ettiği ikamet yerlerine baktığımızda büyük çoğunluğunun (211) büyükşehir belediyesi olan bir ile göç ettiği görülmektedir.

Büyükşehirlerde; sosyal, ekonomik, kültürel, eğitim, sağllk gibi birçok olanakların olması, özellikle iş bulma noktasında daha faz olanağı olmasından dolayı büyükşehirlere göç her zaman için cazip bir tercih 
olmuştur. Büyükşehirlerde de göçle nüfusun artması sonucu farklı sorunların ortaya çıkmasına neden olmuştur. Dengesiz olarak oluşan göç hareketleri büyükşehirlerin sorunlarını daha da artırmıştır. Bu noktada büyükşehir belediye yöneticilerine önemli görevler düşmektedir. Gerekli olan alt yapı ve benzeri hizmetleri yerine getirirken gelecekte nüfusun daha da artacağını hesaba katarak gerekli olan hizmetleri yerine getirmelidir. Duruma göç eden kişi veya kişiler açısından bakıldığında ise illaki büyükşehir birçok yönü ile cazip yerleşim alanlarıdır.

Tablo 6. Katılımcıların Göç Alma Kararlarında Etkileri Olan Kesimlere İlişkin İstatistiki Bilgiler

\begin{tabular}{llll}
\hline Değişkenler & & F & \% \\
\hline & Kimseden Etkilenmedim & 42 & 15,0 \\
Kim veya kimler sizin göç Akrabalarımdan & 60 & 21,4 \\
kararı almanızda etkili & Hemşerilerimden & 141 & 50,4 \\
olmuştur? & Diğer & 26 & 9,3 \\
& Toplam & 11 & 3,9 \\
\hline
\end{tabular}

Tablo 6 incelendiğinde; katılımcıların 42'si $(\% 15,0)$ göç kararı alırken kimseden etkilenmediğini belirtirken, 60'1 $(\% 21,4)$ katılımcı Arkadaşından, $141(\% 50,4)$ katılımcı akrabalarından, $26(\% 9,3)$ hemşerilerinden ve $11(\% 3,9)$ katılımcı diğer kesimlerden etkilendiği bilgileri yer almaktadır. Katılımcıların göç kararı alırken etkili olan kesimlere baktığımızda, büyük çoğunluğunun (141) akrabalarından etkilenerek göç kararı aldıkları görülmektedir.

Tablo 71. Katılımcıları Göç Etmeye Neden Olan Etkenlere İlişkin İstatistiki Bilgiler

\begin{tabular}{llll}
\hline Değişkenler & & F & \% \\
\hline & Aşiret Baskısı & 6 & 2,1 \\
& Kan Davası & 4 & 1,4 \\
& Terör Korkusu & 73 & 26,1 \\
& Eğitim & 17 & 6,1 \\
Sizi göç etmeye & Sağlık & 24 & 8,6 \\
sevk eden en & Siyasi Baskılar & 6 & 2,1 \\
önemli etken nedir? & İşsizlik & 136 & 48,8 \\
& Sosyal Olanakların Yetersizliği & 6 & 2,1 \\
& Tayin & 4 & 2,1 \\
& Diğer & 2 & 0,7 \\
& Toplam & 280 & 100 \\
\hline
\end{tabular}


Tablo 7 incelendiğinde; katılımcıların 6'sı $(\% 2,1)$ göç kararını almalarına neden olan en önemli etkenin aşiret baskısı olduğunu belirtir iken, 4'ü $(1,4)$ kan davasının, 73'ü $(26,1)$ terör korkusunun, 17'si (\%6,1) eğitim, $24^{\prime} \ddot{\mathrm{u}}(\% 8,6)$ sağlık, 6's $(\% 2,1)$ siyasi baskılardan, 136'sı $(48,8)$ işsizliğin, 6's $(\% 2,1)$ sosyal olanakların yetersizliğinin, 4 'ü $(\% 2,1)$ tayin olması ve 2 'si $(\% 0,7)$ diğer nedenlerin olduğu bilgileri yer almaktadır. Katılımcıların göç kararı almalarındaki en önemli etkenin işsizlik olduğu (136 katılımcı) görülmektedir.

Tablo 8. Katılımcıların Göç Ettiği İli ile Bağlantılarının Devam Edip Etmediklerine İlişkin Istatistiki Bilgiler

\begin{tabular}{llll}
\hline Değişkenler & & F & $\%$ \\
\hline Göçle ayrıldığını iliniz & Evet & 241 & 86,1 \\
ile bağlantılarınız halen & Hayır & 39 & 13,9 \\
devam ediyor mu? & Toplam & 280 & 100,0 \\
\hline
\end{tabular}

Tablo 8 incelendiğinde; katılımcların 241'inin (\%86,1) göç ettiği illeri ile bağlantılarının devam ettiği, 39'unun $(\% 13,9)$ ise bağlantılarının devam etmediği bilgileri yer almaktadır. Büyük çoğunluktaki katılımcıların göç ettiği illeri ile bağlantılarının devam ettiği görülmektedir. Bunun en büyük nedeni ise akrabalarının halen göç ettiği ilde yaşıyor olmasıdır.

Tablo 9. Katılımcıların Göç Ettiği Bitlis İlindeki Yerel Yöneticilerin Göçün Önlenmesine Dair Yeterli Düzeyde Çalışmalarının Olup Olmadı̆̆ı Görüşlerine İlişkin İstatistiki Bilgiler

\begin{tabular}{llll}
\hline Değişkenler & & F & $\%$ \\
\hline Size göre yerel yöneticiler & Evet & 48 & 17,1 \\
ilinizdeki göçün önlenmesine & Hayır & 159 & 56,8 \\
dair yeterli düzeyde & Fikrim Yok & 73 & 26,1 \\
çalışmalar yapmakta mıdır? & Toplam & 280 & 100,0 \\
\hline
\end{tabular}

Tablo 9 incelendiğinde; katılımcıların 48'inin $(17,1)$ göç ettiği Bitlis ilindeki yerel yöneticilerin göçün önlenmesine dair yeterli düzeyde çalışmalarının olduğunu belirtirken, 159'unun $(56,8)$ yeterli düzeyde çalışmalarının olmadığına ve 73 'ünün $(26,1)$ ise konu ile ilgili fikirlerinin olmadığ ileri yer almaktadır. Büyük çoğunluktaki katılımcıların göç ettiği Bitlis ilindeki yerel yöneticilerin göçün önlenmesine dair yeterli düzeyde çalışmaların yapılmadığı (159 katılımcı) görüşünde olduğu görülmektedir. 
Tablo 10. Katılımcıların Göç Etmeden Önceki Aylık Gelirlerine İlişkin İstatistiki Bilgiler

\begin{tabular}{llll}
\hline Değişkenler & & F & \% \\
\hline İlinizden göç & 1.000 TL ve Aşağısı & 143 & 51,1 \\
etmeden önceki & 1001 TL-2000 TL & 90 & 32,1 \\
toplam aylık geliriniz & 2001 TL-3000 TL & 36 & 12,9 \\
hakkında bilgi & 3001 TL-5000 TL & 5 & 1,8 \\
verebilir misiniz? & 5001 TL-7000 TL & 6 & 2,1 \\
& 7001 TL-10.000 TL & - & - \\
& 10.001 TL-15.000 TL & - & - \\
& 15.000 TL ve Üzerinde & - & - \\
& Toplam & 280 & 100 \\
\hline
\end{tabular}

Tablo 10 incelendiğinde; katılımcıların 143'ünün $(51,1)$ illerinden göç etmeden önceki aylık gelirinin 1.000 TL ve aşağısında olduğunu belirtirken, 90'1 (\%32,1) 1.001-2000 TL arasinda, 36's1 (\%12,9) 2.001-3000 TL arasinda, 5'i (\%1,8) 3.001-5000 TL arasinda, 6's1 (\%2,1) 5.001-7.000 TL ve 7.000 TL'nin üzerinde aylık geliri olan katılımcının olmadığı bilgileri yer almaktadır. Katılımcıların çoğunluğunun (143 katılımcı) göç etmeden önceki aylık gelirlerinin 1.000 TL ve aşağısında olduğu görülmektedir.

Tablo 11. Katılımcıların Göç Ettiği Yerleşim Alanındaki Aylık Gelirlerine İlişkin İstatistiki Bilgiler

\begin{tabular}{llll}
\hline Değişkenler & & F & \% \\
\hline Ilinizden göç ettikten & 1.000 TL ve Aşă̆ıSı & 4 & 1,4 \\
sonra yani şu & 1001 TL-2000 TL & 39 & 13,9 \\
anki yaşadığınız & 2001 TL-3000 TL & 103 & 36,8 \\
yerleşim alanındaki & 3001 TL-5000 TL & 85 & 30,4 \\
toplam Aylık & 5001 TL-7000 TL & 38 & 13,6 \\
geliriniz hakkında bilgi & 7001 TL-10.000 TL & 6 & 2,1 \\
verebilir misiniz? & 10.001 TL-15.000 TL & 2 & 0,7 \\
& 15.001 TL ve Üzerinde & 3 & 1,1 \\
& Toplam & 280 & 100 \\
\hline
\end{tabular}

Tablo 11 incelendiğinde; katılımcıların 4 'ü $(1,4)$ illerinden göç ettikten sonraki aylık gelirinin 1.000 TL ve aşağısında olduğunu belirtirken, 39'u (\%13,9) 1.001-2000 TL arasinda, 103'ü $(\% 36,8)$ 2.001-3000 TL arasinda, 85'i (\%30,4) 3.001-5000 TL arasinda, 38'i (\%13,6) 5.001-7.000 TL arasında, 6's1 $(\% 2,1) 7.001-10.000 \mathrm{TL}$ arasinda, 2 'si $(\% 0,7)$ 10.001-15.000 TL arasinda ve 3 'ünün $(\% 1,1)$ ise 15.001 TL ve üzerinde aylık geliri olduğu bilgileri yer 
almaktadır. Katılımcıların çoğunluğunun (103 katılımc1) göç ettikten sonraki aylık gelirlerinin 2.001-3.000 TL arasında olduğu görülmektedir.

Tablo 10 ile 11 karşılaştırıldığında; katılımcıların illerinden göç etmeden önceki geliri ile göç ettikten sonrası geliri arasında önemli düzeyde artış olduğunu söyleyebiliriz.

Tablo 12. Katılımcıların Göç Ettikten Sonra Yaşamlarında Herhangi Bir Değişiklik Olup Olmadığına İlişkin İstatistiki Bilgiler

\begin{tabular}{llll}
\hline Değişkenler & & F & \% \\
\hline İlinizden göç ettikten & Evet-Olumlu & 177 & 63,2 \\
sonrasizce yaşamınızda & Evet-Olumsuz & 67 & 23,9 \\
herhangi bir & Hayır & 36 & 12,9 \\
değişiklik oldu mu? & Toplam & 280 & 100,0 \\
\hline
\end{tabular}

Tablo 12 incelendiğinde; katılımcıların 177'sinin $(63,2)$ göç ettikten sonra yaşamlarında olumlu yönde değişiklik olduğunu belirtirken, 67'si $(23,9)$ olumsuz yönde değişiklik olduğunu ve 36's $(12,9)$ ise yaşamlarında herhangi bir değişiklik olmadığını belirtmiştir. Büyük çoğunluktaki katılımcı, illerinden göç ettikten sonra yaşamlarında olumlu yönde değişiklik olduğu görüşündedir.

Tablo 13. Katılımcıların Göç Ettikten Sonraki Yaşamlarındaki En Önemli Değişikliğe İlişkin Istatistiki Bilgiler

\begin{tabular}{llll}
\hline Değişkenler & & F & $\%$ \\
\hline & Ekonomik olanaklarımız arttı & 131 & 46,8 \\
İlinizden göç ettikten & Can güvenliğimizden endişeli değiliz & 66 & 23,6 \\
sonra yaşamınızdaki & Sosyal olanaklarımız arttı & 42 & 15,0 \\
en önemli değişikliği & Sağllk olanaklarımı arttı & 25 & 8,9 \\
belirtebilir misiniz? & Eğitim olanaklarımı arttı & 16 & 5,7 \\
& Toplam & 280 & 100 \\
\hline
\end{tabular}

Tablo 13 incelendiğinde; katılımcıların 131'inin $(46,8)$ göç ettikten sonra yaşamlarındaki en önemli değişikliğin ekonomik olanaklarının arttığ yönünde olduğunu belirtirken; 66'sı $(23,6)$ can güvenliğinden endişeli olmadığını, 42'si $(15,0)$ sosyal olanaklarının arttığını, 25'i $(8,9)$ sağlık olanaklarının arttığını ve 16 'sı $(5,7)$ ise eğitim olanaklarının arttığını belirtmektedir. Tabloda büyük çoğunluğun göç ettikten sonra ekonomik olanaklarının arttığı görüşünde olduğu görülmektedir. 
Tablo 14. Katılımcılarnn Göç Ettikten Sonra Kültürel Uyum Sorunu Yaşayıp Yaşamadıklarına İlişkin İstatistiki Bilgiler

\begin{tabular}{llll} 
Değişkenler & & F & \% \\
\hline İlinizden göç ettikten & Evet & 161 & 57,5 \\
sonra kültürel uyum & Kısmen & 76 & 27,1 \\
sorunu yaşadınız mı? & Hayır & 43 & 15,4 \\
& Toplam & 280 & 100,0 \\
\hline
\end{tabular}

Tablo 14 incelendiğinde; katılımcıların 161'inin (\%57,5) göç ettikten sonra göç ettikleri yerleşim alanında kültürel anlamda uyum sorunu yaşadığını belirtirken, 76'sı $(\% 27,1)$ kısmen ve 43'ü $(\% 15,4)$ ise göç ettiği yerleşim alanında kültürel anlamda uyum sorunu yaşamadığını belirtmiştir. Tabloda büyük çoğunluktaki katılımcıların göç ettiği yerleşim alanında kültürel anlamda sorun yaşadığı görülmektedir.

Ülkenin doğusu ve batısı arasında kültürel anlamda farklılıkların olması doğudan batıya göç etmiş olan kişi veya kişilerin kültürel uyum sorunu yaşamaları doğaldır. Zamanla yaşadıkları kültürel sorun yerini uyuma birakması muhtemeldir.

Tablo 15. Katılımcıların Göç Ettikten Sonra Başka Bir İle Daha Göç Edip Etmediklerine İlişkin İstatistiki Bilgiler

\begin{tabular}{llll}
\hline Değişkenler & & F & $\%$ \\
\hline \multirow{2}{*}{ İlinizden göç ettikten sonra başka bir ilegöçç } & Evet & 51 & 18,2 \\
ettiniz mi? & Hayır & 229 & 81,8 \\
& Toplam & 280 & 100,0 \\
\hline
\end{tabular}

Tablo 15 incelendiğinde; katılımcıların 51'i $(\% 18,2)$ illerinden göç ettikten sonra başka bir ile göç ettiğini belirtirken, 229'u (\%81,8) illerinden göç ettikten sonra başka bir ile göç etmediğini belirtmiştir. Tabloda büyük çoğunluğun illerinde göç ettikten sonra başka bir ile göç etmediği görülmektedir.

Tablo 16 incelendiğinde; katılımcıların 186'sı (\%66,4) göç etmiş oldukları illerindeki en büyük sorunun işsizlik olduğunu belirtirken, 10'u $(\% 3,6)$ göç, 38'i $(\% 13,6)$ terör olayları, 14 'ü $(\% 5,0)$ eğitim, 4'ü $(\% 1,4)$ çarpık kentleşme, 26 'sı $(\% 9,3)$ sağlık ve 2 'si $(\% 0,7)$ ise diğer nedenlerin illerindeki en büyük sorun olduğunu belirtmiştir. 
Tablo16. Katılımcıların Göç Etmiş Oldukları İllerindeki En Büyük Soruna İlişkin İstatistiki Bilgiler

\begin{tabular}{llll}
\hline Değişkenler & & F & \% \\
\hline & İşsizlik & 186 & 66,4 \\
& Göç & 10 & 3,6 \\
Sizce ilinizin & Terör Olayları & 38 & 13,6 \\
en büyük & Eğitim & 14 & 5,0 \\
sorunu nedir? & Çarpık Kentleşme & 4 & 1,4 \\
& Sağllk & 26 & 9,3 \\
& Diğer & 2 & 0,7 \\
& Toplam & 280 & 100 \\
\hline
\end{tabular}

Tabloda katılımcıların büyük çoğunluğun illerindeki en büyük sorunun işsizlik (186 katılımcı) olduğu görülmektedir. İşsizlik, insanları memleketlerinden göç etmeye zorlayan en büyük etken olarak karşımıza çıkmaktadır. İnsanlar iş bulma ümidi ile memleketlerinden başka memleketlere göç etmektedir.

Tablo 17. Katılımcıların Göç Kararlarının Doğru Olup Olmadığına İlişkin İstatistiki Bilgiler

\begin{tabular}{llll}
\hline Değişkenler & & F & $\%$ \\
\hline İlinizden göç etme kararınızın & Evet & 248 & 88,6 \\
doğru olduğunu düşünüyor musunuz? & Hayır & 32 & 11,4 \\
& Toplam & 280 & 100,0 \\
\hline
\end{tabular}

Tablo 17 incelendiğinde; katılımcıların 248'i $(\% 88,6)$ illerinden göç etme kararının doğru olduğunu belirtirken, 32'si $(\% 11,4)$ ise illerinden göç etme kararlarının doğru olmadığını belirtmiştir. Tabloda büyük çoğunluktaki katılımcı illerinden göç etme kararlarının doğru olduğu görüşündedir.

Tablo 18. Katılımcıları Göç Etme Kararların Aldıran Neden veya Nedenlerin Kalkması Durumunda Tekrar İllerine Dönüp Dönmeyeceklerine İlişkin İstatistiki Bilgiler

\begin{tabular}{llll}
\hline Değişkenler & & F & $\%$ \\
\hline İlinizde sizi göç etmeye zorlayan neden veya & Evet & 212 & 75,7 \\
nedenler ortadan kalkmış olsaydı yenidenilinize & Hayır & 68 & 24,3 \\
dönüş yapar mıydınız? & Toplam & 280 & 100,0 \\
\hline
\end{tabular}

Tablo 18 incelendiğinde; katılımcıların 221'i $(\% 78,9)$ illerinden göç etme neden veya nedenlerin ortadan kalkmış olması durumunda yeniden memleketlerine döneceklerini belirtirken, $68^{\prime} \mathrm{i}(\% 24,3)$ ise memleketlerine dönmeyeceklerini belirtmiştir. Tabloda büyük çoğunluktaki katılımcı 
illerinden göç etmeye neden olan etkenlerin kalkması durumunda memleketlerine dönecekleri görüşünde oldukları görülmektedir.

Ülkedeki bölgeler arası hatta iller arası gelişmişlik düzeylerinin imkan ve olanakların farklılık göstermesi gelişmemiş, iş imkanı olmayan, doğup büyüdüğü hayatının belki en iyi günlerini yaşadığı yerleşim alanlarından istemese de göç etmek zorunda kaldığı ama hep bir ümitle yeniden memleketine döneceği hayatının geri kalanını memleketinde yaşayacağı hayali vardir.

Tablo 19. Katılımcıların Öğrenim Durumu ile Cinsiyetlerinin Karşılaştırnlmasına İlişkin Ki- Kare Testi Analiz Sonuçları $(n=280)$

\begin{tabular}{|c|c|c|c|c|c|}
\hline \multirow{2}{*}{ Değişkenler } & \multicolumn{5}{|c|}{ Cinsiyetiniz? } \\
\hline & & & Erkek & Kadın & Toplam \\
\hline \multirow{16}{*}{$\begin{array}{l}\text { Öğrenim } \\
\text { durumununuz? }\end{array}$} & \multirow{2}{*}{ Okur yazar değil } & $\mathrm{F}$ & 18 & 18 & 38 \\
\hline & & $\%$ & 11,9 & 14,0 & 12,9 \\
\hline & \multirow{2}{*}{ Okur Yazar } & $\mathrm{F}$ & 37 & 36 & 73 \\
\hline & & $\%$ & 24,5 & 27,9 & 26,1 \\
\hline & \multirow{2}{*}{ İlköğretim } & $\mathrm{F}$ & 29 & 43 & 72 \\
\hline & & $\%$ & 19,2 & 33,3 & 25,7 \\
\hline & \multirow{2}{*}{ Lise } & $\mathrm{F}$ & 26 & 7 & 33 \\
\hline & & $\%$ & 17,2 & 5,4 & 11,8 \\
\hline & \multirow{2}{*}{ Yüksekokul 2 yıllık } & $\mathrm{F}$ & 16 & 7 & 23 \\
\hline & & $\%$ & 10,6 & 5,4 & 8,2 \\
\hline & \multirow{2}{*}{ Yüksekokul 4 yıllık } & $\mathrm{F}$ & 22 & 16 & 38 \\
\hline & & $\%$ & 14,6 & 12,4 & 13,6 \\
\hline & \multirow{2}{*}{ Yüksek lisans } & $\mathrm{F}$ & 3 & 2 & 5 \\
\hline & & $\%$ & 2,0 & 1,6 & 1,8 \\
\hline & \multirow{2}{*}{ Doktora } & $\mathrm{F}$ & 0 & 0 & 0 \\
\hline & & $\%$ & 0,0 & 0,0 & 0,0 \\
\hline \multirow{2}{*}{ Toplam } & & $\mathrm{F}$ & 151 & 129 & 280 \\
\hline & & $\%$ & 100,0 & 100,0 & 100,0 \\
\hline
\end{tabular}

$X^{2}=14,611 p=0,000^{* *} P<0,01$

Tablo 19'da yer alan katılımcların öğrenim durumu ile cinsiyetlerinin karşılaştırılmasına ilişkin ki kare testi analiz sonucuna göre aralarında bir anlamlılık vardır. Cinsiyeti erkek olan katılımcıların öğrenim durumu, cinsiyeti kadın olanlara göre daha üst düzeydedir. Cinsiyeti kadın olan katılımcların büyük çoğunluğunun $(97$ katılımcı $\% 75,2)$ ilköğretim ve altındaki öğrenim durumuna sahip olduğu görülmektedir. Bu durum cinsiyete göre kadın katılımcıların öğrenim düzeyinin ne kadar düşük seviyede olduğunun göstergesidir. 
Tablo 20. Katılımcıların Cinsiyetleri ile Memleketlerinden Kendilerini Göç Etmeye Neden Olan Etkenlerin Ortadan Kalkması Durumunda Memleketlerine Dönüş Yapıp Yapmayacakları Durumlarının Karşılaştırılmasına İlişkin Ki-Kare Testi Analiz Sonuçları $(n=280)$

\begin{tabular}{llllll}
\hline \multirow{2}{*}{ Değişkenler } & & & \multicolumn{3}{c}{ Cinsiyetiniz? } \\
\cline { 5 - 6 } & & & Erkek & Kadın & Toplam \\
\hline \multirow{2}{*}{ Ilinizden Sizi Göç Etmeye Zorlayan } & \multirow{2}{*}{ Evet } & F & 128 & 84 & 212 \\
\cline { 3 - 6 } Neden ve Nedenler OrtadanKalkmış & $\%$ & 84,8 & 65,1 & 75,7 \\
Olsaydı Yeniden İlinize Dönüş Yapar & \multirow{2}{*}{ Hayır } & F & 23 & 45 & 68 \\
mıydınız? & $\%$ & 15,2 & 34,9 & 24,3 \\
\hline Toplam & & F & 151 & 129 & 280 \\
& & $\%$ & 100,0 & 100,0 & 100,0 \\
\hline
\end{tabular}

$X^{2}=14,611 p=0,000^{* *} P<0,01$

Tablo 20'de yer alan katılımciların Cinsiyetleri ile memleketlerinden kendilerini göç etmeye neden olan etkenlerin ortadan kalkması durumunda memleketlerine dönüş yapıp yapmayacakları durumlarının karşılaştırılmasına ilişkin ki kare testi analiz sonucuna göre aralarında bir anlamlılık vardır. Cinsiyeti erkek olan katılımcıların 128'i (\%84,8), kadın katılımcların ise $84^{\prime}$ ü $(\% 65,1)$ illerinden kendilerini göç etmeye neden olan etkenlerin ortadan kalkması durumunda memleketlerine döneceğini belirtirken, Cinsiyeti erkek olan katılımcların 23'ü (\%15,2), kadın katılımcıların ise 45'i $(\% 34,9)$ illerinden kendilerini göç etmeye neden olan etkenlerin ortadan kalkması durumunda memleketlerine geri dönmeyeceklerini belirtmiştir.

İllerinden kendilerini göç etmeye neden olan etkenlerin ortadan kalkması durumunda memleketlerine dönmeyeceğini belirten 68 katılımcının büyük çoğunluğunu (45 katılımcı) kadın katılımcılardan olduğu tabloda öne çıkan bilgiler arasındadır. Bu tabloya göre kadınların erkeklere göre daha çok göç ettiği yerleşim alanında kalma isteklerinin olduğunu söyleyebiliriz.

\section{Sonuç}

Göç kararı insanların geleceğini olumlu ya da olumsuz yönde etkileyebileceği bir süreçtir. Bu bakımdan, göç edilecek yer belirlenirken çok yönlü düşünülüp rasyonel alınan kararlara göre hareket edilmelidir. Aksi 
durumda göç edilen yerden sonucu daha vahim olan durum veya durumlarla karşılaşılabilinir. Böylesi bir durumda da insanlar göç ettikleri yerden başka yerleşim alanlarına yeniden göç edebiliyor. Bu da insanların belirli kayıplarına neden olmaktadır. Bu anlamda göç kararı alınırken iyi düşünülüp analizler yapıldıktan sonra gerçekleştirme aşamasına geçilmelidir.

Alan araştırması yapılan Bitlis ilinde insanların göç etme sebeplerinin başında işsizlik ardından terör olayları, sağlık ve eğitim olanaklarının yetersizliği gelmektedir. İnsanlar memleketlerinden zorunlu olarak istemleri dışında sosyo-ekomik yapıları farklı olan başka bir memlekete taşınmaktadır. Zorunlu olan bu göç hareketleri, kimileri için her şey istediği ve beklediği gibi sonuçlanırken, kimileri içinse olumsuz yönde sonuçlanabilmektedir. Yaşanan bu olumsuz sonuçlar, göç edenler arasında sosyal, kültürel ve psikolojik travmalara neden olmaktadır.

Günümüzdeki Bitlis ilinde olduğu gibi göçe etki eden etkenler arasındaki en önemli faktör ekonomik faktördür. Şehirlerde görülen işsizlik nedeni ile insanlar genç yaşta doğup büyüdükleri memleketinden ayrılmak zorunda kalmaktadır. Göç edilen yerle birlikte göç edilen yerlerde de nüfusun artışına paralel olarak farklı sorunları da ortaya çıkarmaktadır. Büyükş̧ehirlere ya da gelişim aşamasında olan şehirlere göçün önlenmesi için gelişimi geriye doğru giden veya durmuş olan şehirlere yeni işletmeleri teşvik edici adımlar atılmalı ve Organize Sanayi Bölgelerinin yaygınlaştırılması ile birlikte mevcut olan Organize Sanayi Bölgelerinin de geliştirilmesine yönelik destekleyici faaliyetlerde bulunulması önem arz etmektedir. Özelde ise çalışmamızda yer alan Bitlis ili ve ilçelerine yönelik teşviklerin artırılması, Organize Sanayi Bölgelerinin kurulması, Van Gölü çevresinde bulunan Adilcevaz, Ahlat ve Tatvan ilçelerine turizmi teşvik edici yatırımların artırılması ve yeni tesislerin kurulması sonucu göç olgusunun azalacağı, hatta daha önce göç eden insanların yeniden kendi memleketlerine döneceği düşünülmektedir. 


\title{
EXTENDED ABSTRACT
}

\section{Causes of Internal Migration and Evaluation: Province of Bitlis Example}

\author{
Vedat Yilmaz \\ Yuzuncuyll University
}

Migration is a universal problem because it is a common problem of all countries. The subject of migration, which is defined as the situation of people being replaced by geographic expressions, is a phenomenon that has been going on for centuries. People have to migrate due to factors such as social, cultural, economic, administrative and environmental. Although some of the migrations are voluntary, the majority of the migrations are generally made after the compulsory cases. The concept of migration is the process of livelihood of people, failure to meet their basic needs, natural disasters such as earthquakes and floods, and the relocation of societies from one place to another due to reasons and reasons similar to the conflicts between each other. In time, the reasons for migration varied, with the development of certain cities in areas such as social, cultural, educational and economic, as well as people from underdeveloped or underdeveloped settlements to developed settlements. Thus, the cities where people emigrated grew further and developed, and other places get even smaller and the development is hindered. Population is an important force in the development of cities. It is important to know that this power must be used correctly and in time. If the necessary infrastructure preparations are made by taking into account that the population will increase in the future with the increase of the population, the increasing population in the city plays an important role in the development of the city in many areas. Otherwise, new problems in the city will be inevitable.

As in all countries in the world, there are both immigrants and emigrants in Turkey, as well as from within the country's own boundaries, migrating from one living space to another. The migration within the borders of the country is called as internal migration and the migration to the 
country beyond the borders of the country is called as migration. In this way, people faced to change the residential areas from time to time for certain reasons.

Migration is one of the most important factors that change the social, economic and cultural structures of societies. In other words, the phenomenon of immigration influences the social structure, but it has the characteristics of changing it. This phenomenon is one of the key structural problems in Turkey since more than half a century. This spatial distribution in the demographic structure has manifested itself in both the emigrant and the immigrated residential areas. There are different reasons for this process and it has been far beyond a process that started and ended in a certain place. Today, many factors that cause and nurture this process constitute the primary cause of social mobility. Migrations in Turkey are made especially for social, economic and cultural reasons as well as fear of security.

After the 1950, wave of migration in Turkey has gained speed. The flow of migration from the East and Southeast Anatolia Region to the western regions has increased. In the study, it has been tried to inform about the mentioned internal migration which is rarely mentioned in recent years. In this context, Bitlis province, which has a long history, was taken as a sample in order to reveal the elements that cause people to migrate to settlements other than settlements where they were born and grown. A total of 280 participants who have lived in a certain period of time within the borders of the province of Bitlis were surveyed between January 20, 2017 and March 15, 2017. The data obtained from the questionnaires were analyzed and interpreted using the SPSS (Statistical Package for Social Science 22.0) statistical package program. In the study, information about the causes of migration and migration concept have given and solutions have been made.

The reason of emigration of people in Bitlis province, which is being investigated in the field, is the lack of terror events, health and education opportunities after unemployment. Involuntarily people move from their homeland compulsorily to another country with different socio-economic structures. These migratory movements, which are compulsory, may result in negative consequences for others while everything is as desired and 
expected for some. These negative results cause social, cultural and psychological trauma among the migrants.

As in today's Bitlis province, the most important factor affecting migration is the economic factor. Due to the unemployment in the cities, people are forced to leave their hometown where they are born and grew up at a young age. In parallel with the increase in the population in the places where the migrants are migrated, different problems arise. In order to prevent migration to metropolitan or developing cities, steps should be taken to encourage new enterprises to move backwards or to those cities that have progressed, and it is important to support the development of Organized Industrial Zones with the promotion of Organized Industrial Zones. In private sector, increasing the incentives for Bitlis province and its districts in our study, establishment of Organized Industrial Zones, increasing tourism investment incentives to Adilcevaz, Ahlat and Tatvan districts around Van Lake and the establishment of new facilities will decrease the phenomenon of migration and even re-migrate the people who migrated earlier is thought to return to the country.

\section{Kaynakça / References}

Akan, Y. ve Arslan, İ. (2008). Göç ekonomisi:Türkiye üzerine bir uygulama. Bursa: Ekin Kitabevi.

Akşit, B. (1998). İ̧̧ göçlerin nesnel ve öznel toplumsal tarihi üzerine gözlemler köy tarafindan bir bakış: Türkiye'de iç göç, içinde (22-37). İstanbul: Türkiye Ekonomik ve Toplumsal Tarih Vakfı Yayını.

Başel, H. (2007). Türkiye'de nüfus hareketlerinin ve iç göçün nedenleri. Sosyal Siyaset Konferanslarn Dergisi, 53, 515-542.

Bulut, Y. ve Eraldemir, Z. (2015).Göç olgusunun farklı boyutlarıyla Hatay İli İskenderun ve Dörtyol ilçeleri ölçeğinde incelenmesi, (Y. Bulut Ed.) Uluslararası Göç ve Mülteci Sorunun Çözümünde Kamu Yönetiminin Rolü, içinde (13-38). Kocaeli:Umuttepe Yayınları.

Eren, V. ve Aydın A. (2016). Türkiye'deki kentleşme sürecinde yeni bir durum: Suriyeli kentliler. Çukurova Araştırmaları Dergisi, 2(1), 3138. 
Etzo, I. (2008). Internal migration a review of the literature. MPRA Munich Personel RePEc Archive, 28.06.2017 tarihinde, http://mpra.ub.unimuenchen.de/8783 adresinden erişildi.

Faist, T. (2003). Uluslararası göç ve ulusaşırı toplumsal alanlar, (A.Zana Gündoğan ve C.Acar, çev.). Ankara:Bağlam Yayınları.

Gündüz, M. ve Yetim, N. (1997). Terör ve göç, II.Ulusal Sosyoloji Kongresi Toplum ve Göç Bildiriler Kitabı içinde (109-116), Ankara,20-22 Kasım 1996.

İçduygu, A. ve Ünalan, T. (1998). Türkiye'de iç göç sorunsal alanları ve araştırma yöntemleri, Türkiye'de İç Göç, içinde (38-55). İstanbul:Türkiye Ekonomik ve Toplumsal Tarih Vakfı Yayını.

Karpat, K. H. (2013). Osmanlıdan günümüze etnik yapılanma ve göçler. İstanbul: Timaş Yayınları.

Keleş, İ. (1997). Türkiye'de göç eğilimleri ve şehirleşme süreci. Gazi Üniversitesi Hukuk Fakültesi Dergisi, 1(2), 167- 187.

Keleş, R. (1998). Kentleşme politikası. Ankara:İmge Kitabevi.

Koçak, Y. ve Terzi, E. (2012). Türkiye'de göç olgusu, göç edenlerin kentlere olan etkileri ve çözüm önerileri. Kafkas Üniversitesi İktisadi ve İdari Bilimler Fakültesi Dergisi, 3(3),163-184.

Özer, İ. (2004). Kentleşme kentlileşme ve kentsel değişme. Bursa:Ekin Kitabevi.

Tekeli, İ. (1998). Türkiye'de iç göç sorunsalı yeniden tanımlama aşamasına geldi, Türkiye'de İç Göç içinde (7-21). İstanbul:Türkiye Ekonomik ve Toplumsal Tarih Vakfi.

Serdar, T. M. (2017). Bitlis. Bitlis: Bitlis İl Kültür ve Turizm Müdürlüğü Yayınları, No: 15.

Serdar, T. M. (2010). Rüyalar şehri Bitlis. İstanbul:Hamle Yayınları.

Sarıteke İ., Kahraman Ö. F. ve Aydın. A. (2018). Türkiye'deki Suriyeli nüfusun hukuki statüsü ile ilgili bir analiz. Turkish Studies, 13(7), 383-396.

Öner, S. ve Kaçmazoğlu H. B. (1996). Göç Olgusu ve Doğu Anadolu, II. Sosyoloji Kongresi: Toplum ve Göç içinde (371-379). No: 2046, Ankara, 20-22 Kasım 1996.

http://www.bitliskulturturizm.gov.tr/TR,56204/tarihce.html, adresinden 10/03/2019 tarihinde erişilmiştir.

http://www.cografya.gen.tr/tr/bitlis/, adresinden 10/03/2019 tarihinde erişilmiştir. 
http://www.cografya.gen.tr/tr/bitlis/ekonomi.html, adresinden 10/03/2019 tarihinde erişilmiştir.

https://www.nufusu.com/il/bitlis-nufusu, adresinden 10/03/2019 tarihinde erişilmiştir.

https://www.nufusu.com/turkiyenin-en-kalabalik-sehirleri, adresinden 11/03/2019 tarihinde erişilmiştir.

http://www.illerarasimesafe.com/adilcevaz-bitlis_bitlis/yolharitasi, adresinden 11/03/2019 tarihinde erişilmiştir.

http://www.illerarasimesafe.com/bitlis_ahlat-bitlis/yolharitasi, adresinden 11/03/2019 tarihinde erişilmiştir.

http://www.illerarasimesafe.com/guroymak-bitlis_bitlis/yolharitasi , adresinden 08/03/2019 tarihinde erişilmiştir.

http://www.illerarasimesafe.com/bitlis-hizan_bitlis, adresinden 08/03/2019 tarihinde erişilmiştir.

http://www.illerarasimesafe.com/mutki-bitlis_mutki-bitlis/yolharitasi, adresinden 11/03/2019 tarihinde erişilmiştir.

http://www.illerarasimesafe.com/bitlis_tatvan-bitlis/yolharitasi, adresinden 11/03/2019 tarihinde erişilmiştir.

http://www.tuik.gov.tr, adresinden 10/03/2019 tarihinde erişilmiştir.

\section{Kaynakça Bilgisi / Citation Information}

Yılmaz, V. (2019). İç göçün nedenleri ve değerlendirilmesi: Bitlis ili örneği. OPUS-Uluslararası Toplum Araştırmaları Dergisi, 11(18), 1709-1735. DOI: 10.26466/opus.562603 